\title{
Evaluation of Antibacterial and Synergistic/Antagonistic Effect of Some Medicinal Plants Extracted by Microwave and Conventional Methods
}

\author{
Kamal E. M. El Kahlout ${ }^{*}$, Waseem El Borsh ${ }^{1}$, Adil Aksoy², Abboud Y. El Kichaoi ${ }^{3}$, \\ Mahmoud W. El Hindi', Nizam M. El Ashgar ${ }^{4}$ \\ ${ }^{1}$ Department of Biology \& Biotechnology, Islamic University, Gaza, Palestine \\ ${ }^{2}$ EsKil of High School, Laboratory Veterinary Science, Aksaray University, Aksaray, Turkey \\ ${ }^{3}$ Biological Control Unit, Department of Biology \& Biotechnology, Islamic University, Gaza, Palestine \\ ${ }^{4}$ Department of Chemistry, Islamic University, Gaza, Palestine \\ Email: *kelkahlout@iugaza.edu.ps
}

How to cite this paper: El Kahlout, K.E.M., El Borsh, W., Aksoy, A., El Kichaoi, A.Y., El Hindi, M.W. and El Ashgar, N.M. (2020) Evaluation of Antibacterial and Synergistic/ Antagonistic Effect of Some Medicinal Plants Extracted by Microwave and Conventional Methods. Journal of Biosciences and Medicines, 8, 69-79.

https://doi.org/10.4236/jbm.2020.89006

Received: July 11, 2020

Accepted: September 6, 2020

Published: September 9, 2020

Copyright $\odot 2020$ by author(s) and Scientific Research Publishing Inc. This work is licensed under the Creative Commons Attribution International License (CC BY 4.0).

http://creativecommons.org/licenses/by/4.0/ (c) (i) Open Access

\begin{abstract}
The purpose of the study was to evaluate the efficiency of the microwave (MW) extraction method by comparing it with a conventional method through evaluation of antimicrobial and synergism/antagonism activity of each aquatic and ethanolic extracts samples, which were extracted from the dried plants (Ficus sycomorus leaves, Lawsonia inermis leaves and Glycerrhiza glabra Linn.). Nine samples of each plant for both solvents were irradiated with MW at several power outputs $(180 \mathrm{w}, 360 \mathrm{w}$, and $540 \mathrm{w})$ in several interval times (1, 2 and 3 minutes). The antibacterial activities of extracts and the synergistic effect between plants and antibiotics were evaluated using disk diffusion method against clinical isolated Staphylococcus aureus and Escherichia coli. The result revealed that the inhibition zone for more than $50 \%$ using aquatic and ethanolic samples results (extracted in two minutes and MW power $180 \mathrm{w}$ ) had shown the optimum extract and better antibiotic activity for each plant. Also, the results of ethanolic extracts used against selected microorganisms showed antimicrobial and synergistic effect with most antibiotics better than aquatic extracts. Our results indicate the possibility of using MW apparatus as an extractor to obtain bioactive compounds from plants and thus used in the treatment of bacterial infections, and some results of this study were encouraging. However, the antagonistic reactions of some extracts with some antibiotics and their use in combination should be further studied for in vitro activities. It is clearly a need to be furthermore evaluated, to identify the effective components, the mode of action and the possible tox-
\end{abstract}


ic effect in-vivo of these ingredients.

\section{Keywords}

Microwave, Antibacterial, Synergistic, Antagonistic, Aquatic Extract \& Ethanolic Extract

\section{Introduction}

Research in herbal medicine has increased in developing countries as a way to rescue ancient traditions as well as an alternative solution to health problems. Therefore, with the increasing acceptance of traditional medicine as an alternative form of health care, the screening of medicinal plants for active compounds has become very important [1].

The emergence and spread of multidrug resistance as a phenomenon among bacterial pathogens has been a major problem confronting the field of antibacterial chemotherapy in modern years. However, it has been found that, in addition to the production of intrinsic antimicrobial compounds, some medicinal plants also produce multidrug resistance inhibitors which enhance the activities of antibiotics against multidrug resistant bacteria pathogens. It is this finding that prompted efforts in screening of crude extracts for synergistic interaction with standard antibiotics against resistant bacteria as this would have the way for possible isolation of multidrug resistance inhibitors of plant origin [2].

Nowadays, microwaves are used for extraction of bioactive compounds from plant materials because of tremendous research interest and potential [3] [4]. Conventional extraction techniques are time-consuming and require more solvent and most of them are not suitable for thermolabile constituents [5]. In MW, the process acceleration and high extraction yield may be the result of a synergistic combination of two transport phenomena: heat and mass gradients working in the same direction. On the other hand, in conventional extractions, the mass transfer occurs from inside to the outside, although the heat transfer occurs from the outside to the inside of the substrate [6].

Fig, (Ficus carica), plant of the mulberry family (Moraceae), and its edible fruit. It is one of the old and historic plant species in the Palestine coastal valley and the study area as well. It is known and called in Palestine as Balami or Jummaze. The antibacterial activity of $F$. sycomorus could be related to the presence of bioactive compounds, such as tannins, saponins, flavonoids, steroids, anthraquinone glycosides and reducing sugars [7].

$L$. inermis belongs to family Lythraceae [8]. L. inermis is commonly known as Henna or Mhendi and abundantly available in tropical and subtropical areas. Henna leaves have been used traditionally in northern Nigeria as a remedy against diarrhea, dysentery and other related diseases. The main constituents of the plant are carbohydrates, glycosides, tannins, phenolic compounds and gums and mucilage [9]. 
G. glabra Linn, commonly known as liquorice and sweet wood belongs to Leguminosae family. Reported antibacterial activity because of the presence of secondary metabolites such as; saponins, alkaloids, flavonoids [10] [11]. Thereby, this study tried to throw light on the importance of extraction step of bioactive compounds from F. sycomorus, L. inermis and G. glabra by using microwave irradiation through evaluation of antimicrobial and synergism/antagonism activity of each aquatic and ethanolic activity of the extracts.

\section{Materials and Methods}

\subsection{Plant Sample Collection}

The plant materials used in this study consisted of F. sycomorus, L. inermis and G. glabra which were collected from different areas in Gaza strip (Table 1).

\subsection{Chemicals and Culture Media}

Three types of media were used for carrying out this study, Nutrient broth, $\mathrm{Nu}$ trient agar and Muller Hinton agar. Distilled water and ethanol was used for extraction process. Cefotaxime, Ofloxacin, Ciprofloxacin, Levofloxacin, Nitrofurantoin, ceftriaxone, chloramphenicol, and Amikacin used as reference antibiotics (Table 2). Dimethyl sulfoxide (DMSO) and ethanol $80 \%$.

\subsection{Bacteria}

Clinical isolated species of $S$. aureus, and E. coli were obtained from Biology \& Biotechnology Department at the Islamic University of Gaza (IUG), and were maintained on DMSO at $-80^{\circ} \mathrm{C}$ for further experiments.

Table 1. Plant materials used in this study.

\begin{tabular}{ccc}
\hline Plant/Part used & Place & Time of collection \\
\hline F. sycomorus/leaves & Jabalia-North of Gaza & March \& April 2015 \\
L. inermis/leaves & Market & April 2015 \\
G. glabra/roots & Market & April 2015 \\
\hline
\end{tabular}

Table 2. List of antibiotic potency.

\begin{tabular}{cccc}
\hline Antibiotics & Symbol & Antibiotics potency & Manufactured by \\
\hline Cefotaxime & CTX & $30 \mu \mathrm{g}$ & Bioanalyse, Turkey \\
Ofloxacin & OF & $5 \mu \mathrm{g}$ & Himedia, Indian \\
Ceftriaxone & CTR & $30 \mu \mathrm{g}$ & Himedia, Indian \\
Amikacin & AK & $30 \mu \mathrm{g}$ & Bioanalyse, Turkey \\
Chloramphenicol & C & $30 \mu \mathrm{g}$ & Bioanalyse, Turkey \\
Ciprofloxacin & CI & $5 \mu \mathrm{g}$ & Bioanalyse, Turkey \\
Levofloxacin & LEV & $5 \mu \mathrm{g}$ & Bioanalyse, Turkey \\
Nitrofurantoin & F & $300 \mu \mathrm{g}$ & Bioanalyse, Turkey \\
\hline
\end{tabular}




\subsection{Microwave Apparatus}

Commercial microwave oven (Panasonic) with ten power levels (80 to $800 \mathrm{~W}$ ) was used NN-SE996S.

\subsection{Preparation of Plant Extract}

A total of plants extract were used in this study as shown in Table 3.

\subsection{Preparation of Inoculums}

According to (Mohammed et al., 2015) stock cultures were maintained at $4^{\circ} \mathrm{C}$ on nutrient agar slants for bacteria. Active cultures for experiments were prepared by transferring $0.5 \mathrm{ml}$ of culture to $5 \mathrm{ml}$ of nutrient broth and incubated at $37^{\circ} \mathrm{C}$ for 24 hours. The optical density of each active culture adjusted to 0.1 at $625 \mathrm{~nm}$, using fresh broth to give standard inocula of 106 colony forming units (CFU) per ml [3] [14] [15].

\subsection{Paper Disk Diffusion Assay}

A modification procedure was followed to evaluate of antibacterial activity of plant extracts. Standardized inoculums of each bacterium, i.e., $10^{6} \mathrm{CFU}$ (Colony Forming Units)/ml to 0.1 at $625 \mathrm{~nm}$ was introduced onto the surface of sterile Nutrient agar plates and a sterile cotton swab was used for even distribution of inoculums. After a few minutes, sterile filter paper discs of $5 \mathrm{~mm}$ diameter were placed on the surface of inoculated and labeled nutrient agar plates and impregnated with $20 \mu \mathrm{L}$ of known concentration of extracts $(200 \mathrm{mg} / \mathrm{ml})$ for aquatic and ethanolic extracts. Sterile paper discs containing Dimethyl sulfoxide alone was served as negative control. The plates were placed at $4^{\circ} \mathrm{C}$ for $2 \mathrm{~h}$. and then subsequently incubated at $37^{\circ} \mathrm{C}$ for $24 \mathrm{Hrs}$. After incubation, the growth inhibition rings were quantified by measuring the diameter of the zone of inhibition in $\mathrm{mm}$. For each test solution, three replicates were maintained [16].

\subsection{Synergism/Antagonism between Plant Extract and Antibiotics}

A modification procedure was followed to investigate the synergistic effect. The bacterial cultures were grown in sterile nutrient broth medium at $37^{\circ} \mathrm{C}$. After $4 \mathrm{~h}$ of growth, standardized inoculums of each bacterium, i.e., $10^{6} \mathrm{CFU} / \mathrm{ml}$ to 0.1 at

Table 3. Preparation of plant extract.

\begin{tabular}{|c|c|c|c|}
\hline \multicolumn{2}{|c|}{ Soxhlet extraction } & \multicolumn{2}{|c|}{ Microwave extraction } \\
\hline Aqueous extraction & Ethanol extraction & Aqueous extraction & Ethanol extraction \\
\hline Air dried powder $(20 \mathrm{~g})$ was & Air dried powder $(20 \mathrm{~g})$ was & $4 \mathrm{~g}$ of the powder was mixed with & $4 \mathrm{~g}$ of the powder was mixed with \\
\hline $\begin{array}{l}\text { added to } 150 \mathrm{ml} \text { of distilled water, } \\
\left(100^{\circ} \mathrm{C}\right) \text {, as a solvent for } 8 \text { hours }\end{array}$ & $\begin{array}{l}\text { added to } 150 \mathrm{ml} \text { of } 80 \% \text { ethanol, } \\
\left(78.5^{\circ} \mathrm{C}\right) \text {, as a solvent for } 8 \text { hours, }\end{array}$ & $\begin{array}{l}100 \mathrm{ml} \text { distilled water. Then } \\
\text { the mixture was irradiated with }\end{array}$ & $\begin{array}{l}100 \mathrm{ml}(80 \%) \text { ethanol. Then the } \\
\text { mixture was irradiated with }\end{array}$ \\
\hline $\begin{array}{l}\text { using soxhlet equipment. Then } \\
\text { the extract was filtered and }\end{array}$ & $\begin{array}{l}\text { using soxhlet equipment. Then } \\
\text { the extract was filtered and }\end{array}$ & $\begin{array}{l}\text { microwave at several power output } \\
(180,360 \text { and } 540) \text { in several }\end{array}$ & $\begin{array}{c}\text { microwave at several power (180, } \\
360 \text { and 540) in several interval }\end{array}$ \\
\hline allowed to evaporate in oven & allowed to evaporate in oven & interval times (1,2 and 3$)$ minuets & times (1, 2 and 3$)$ minuets to \\
\hline$\left(45^{\circ} \mathrm{C}\right)$ through $48 \mathrm{hr}[12]$ & $\left(45^{\circ} \mathrm{C}\right)$ through $48 \mathrm{hr}[12]$ & to obtain nine samples [13]. & obtain nine samples [13]. \\
\hline
\end{tabular}


$625 \mathrm{~nm}$ was introduced onto the surface of sterile Nutrient agar plates and a sterile cotton swab was used for even distribution of inoculums. After a few minutes, the antibiotic filter paper disk of $5 \mathrm{~mm}$ in diameter placed on the surface of inoculated and labeled Nutrient agar plates and impregnated with $20 \mu \mathrm{L}$ of known concentration of extracts $(200 \mathrm{mg} / \mathrm{ml})$ for aquatic and ethanolic extracts. The plates were incubated at $37^{\circ} \mathrm{C}$ for $24 \mathrm{~h}$. The diameters of cleared zones were measured and compared with that of the antibiotic alone. For each test solution, three replicates were maintained [7].

\section{Results and Discussion}

\subsection{Evaluation of Antibacterial Activity of Plant Extracts and the Synergistic/Antagonistic Effect}

The results in Tables 4-9 showed that ethanolic extracts used against selected microorganisms offered antimicrobial and synergistic effect with most antibiotics better than aquatic extracts. In case of aquatic extracts; $G$. glabra had the best antibitic activity against $E$. coli. In case of ethanolic extracts, the best activity was observed with $G$. glabra against $E$. coli. Also, synergistic activity of the plant extracts, in case of aquatic extracts; $F$. sycomorus had the best synergism against $S$. aureus and $E$. coli. In case of ethanolic extracts, the best synergism was observed with $L$. innermis against E. coli, and with $F$. sycomorus against $S$. aureus. High levels of antagonism reaction exhibited by all aquatic plant extracts of both methods when combined with antibiotics which showed sensitivity when tested as alone against $S$. aureus. Also all ethanolic extracts of L. innermis and G. glabra of both methods exhibited antagonism reactions when combined with antibiotics which showed sensitivity when tested as alone against $S$. aureu. In addition, antagonism reaction occurred against $E$. coli for antibiotics which were resistant against $E$. coli when combined with aquatic and ethanolic extracts for both methods of $G$. glabra which showed sensitivity when tested as alone against $E$. coli. In addition, dilution reactions against $S$. aureus occurred with some antibiotics combined with ethanolic extracts of $F$. sycomorus \& L. innermis.

Table 4. Antibacterial activity of antibiotics against $E$. coli and $S$. aureus by disc diffusion method.

\begin{tabular}{ccc}
\hline Microorganism & S. aureus & E. coli \\
\hline Antibiotics & \multicolumn{2}{c}{ Inhibition zone $(\mathrm{mm})$} \\
Ofloxacin & $\mathrm{R}$ & $25 \pm 1.0^{*}$ \\
Ceftriaxone & $\mathrm{R}$ & $\mathrm{R}$ \\
Ciprofloxacin & $\mathrm{R}$ & $\mathrm{R}$ \\
Cefotaxime & $\mathrm{R}$ & $22 \pm 1.58^{*}$ \\
Amikacin & $\mathrm{R}$ & $\mathrm{R}$ \\
Chloramphenicol & $\mathrm{R}$ & $\mathrm{R}$ \\
Levofloxacin & $\mathrm{R}$ & $25 \pm 0.7^{*}$ \\
Nitrofurantoin & $\mathrm{R}$ & $25 \pm 2.0^{*}$ \\
\hline
\end{tabular}

$\mathrm{mm}=$ millimeter,${ }^{\star}$ Mean \pm Standard Deviation, $\mathrm{R}=$ Resistance. 
K. E. M. El Kahlout et al.

Table 5. Antibacterial effect of G. glabra extracts against S. aureus and E. coli.

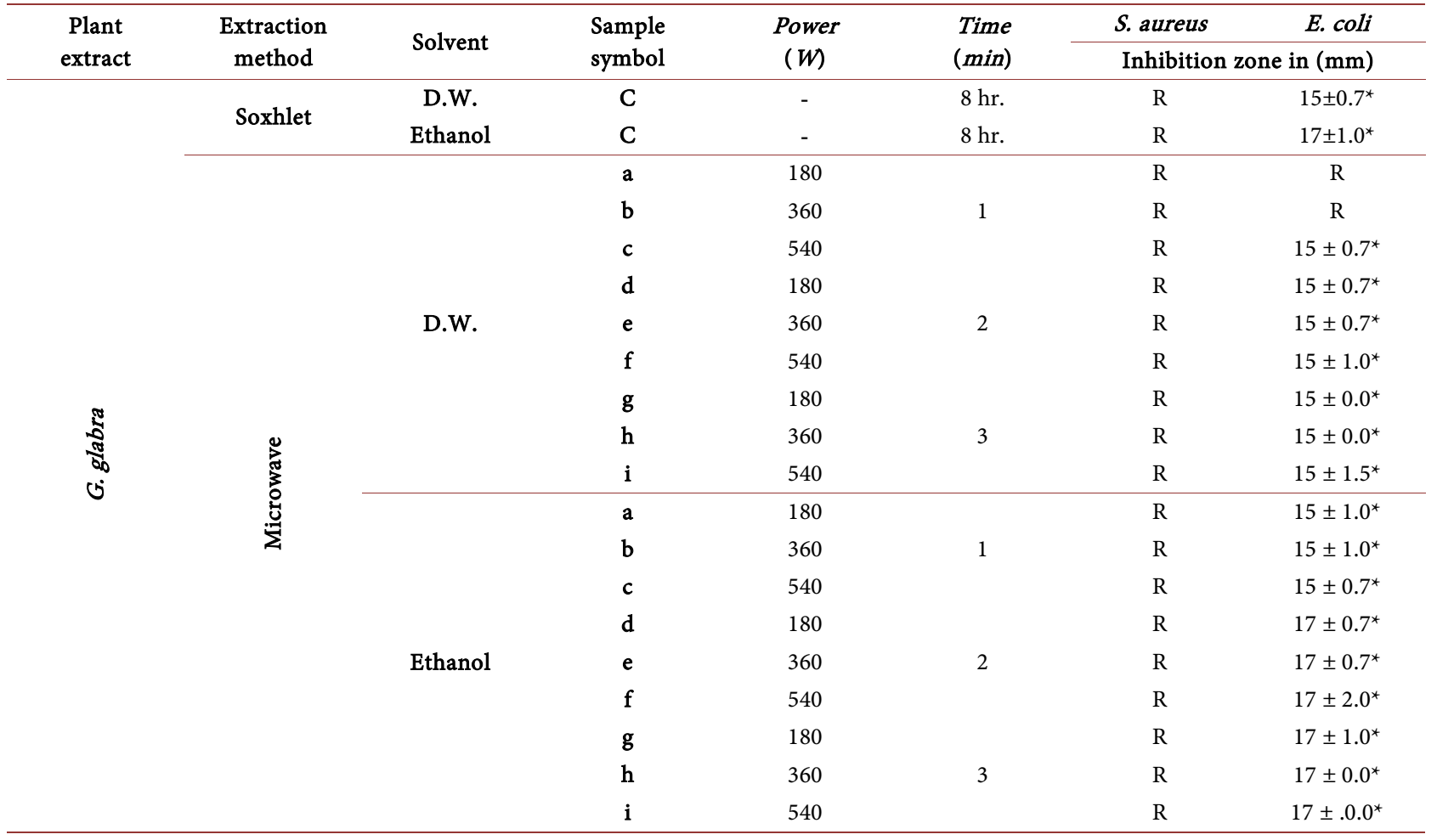

$\mathrm{mm}=$ millimeter, ${ }^{\star}$ Mean \pm Standard Deviation, $\mathrm{n}=3, \mathrm{R}=$ Resistance.

Table 6. Synergistic/antagonistic effect of F. sycomorus extracts and antibiotics against $S$. aureus.

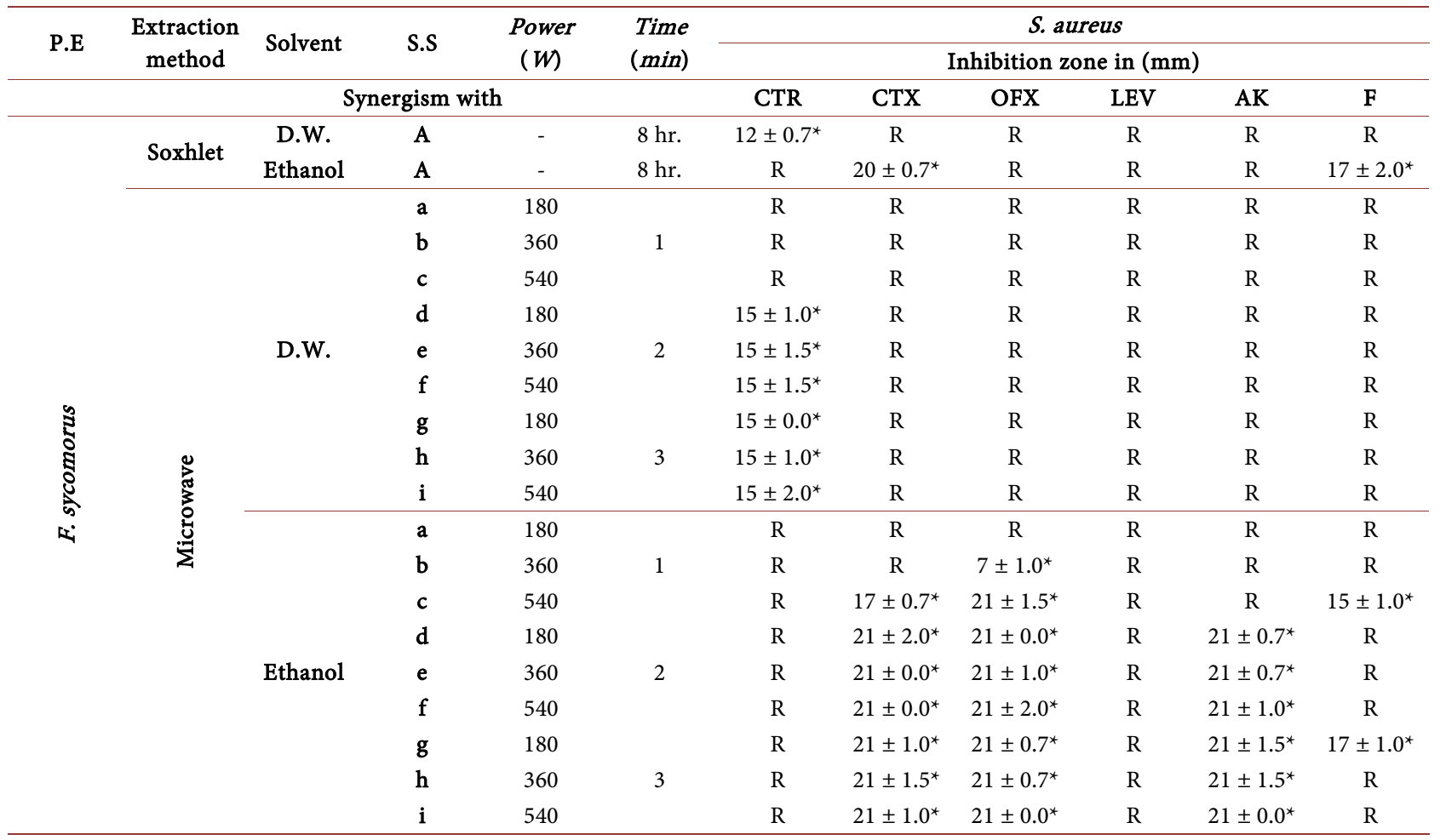

$\mathrm{mm}=$ millimeter, ${ }^{\star}$ Mean \pm Standard Deviation, $\mathrm{n}=3, \mathrm{R}=$ Resistance, D.W.: Distilled water. P.E.: Plant Extract, S.S.: Sample Symbol, F: Nitrofurantoin; OFX: Ofloxacin; LEV: Levofloxacin; AK: Amikacin; CTX: Cefotaxim. 
Table 7. Synergistic/antagonistic effect of $F$. sycomorus extracts and antibiotics against $E$. coli.

\begin{tabular}{|c|c|c|c|c|c|c|c|c|c|c|c|}
\hline \multirow{3}{*}{ P.E } & \multirow{3}{*}{$\begin{array}{c}\text { Extraction } \\
\text { method }\end{array}$} & \multirow{2}{*}{ Solvent } & \multirow{2}{*}{ S.S } & \multirow{2}{*}{$\begin{array}{c}\text { Power } \\
(W)\end{array}$} & \multirow{3}{*}{$\begin{array}{l}\text { Time } \\
\text { (min) }\end{array}$} & \multicolumn{6}{|c|}{ E. coli } \\
\hline & & & & & & \multicolumn{6}{|c|}{ Inhibition zone in (mm) } \\
\hline & & \multicolumn{3}{|c|}{ Synergism with } & & CTR & CTX & OFX & LEV & $\mathrm{AK}$ & F \\
\hline \multirow{20}{*}{ 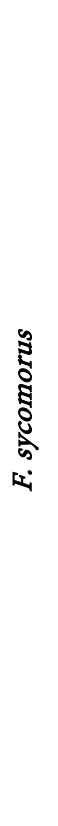 } & Sorblet & D.W. & A & - & $8 \mathrm{hr}$. & $16 \pm 0.0^{*}$ & $\mathrm{R}$ & $\mathrm{R}$ & $\mathrm{R}$ & $\mathrm{R}$ & $\mathrm{R}$ \\
\hline & \multirow{19}{*}{ 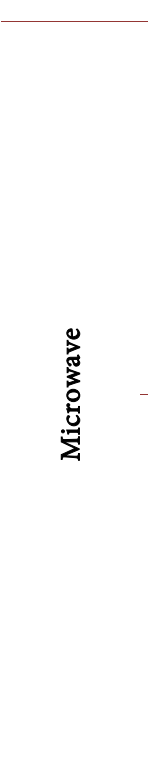 } & Ethanol & A & - & $8 \mathrm{hr}$. & $\mathrm{R}$ & $\mathrm{R}$ & $\mathrm{R}$ & $\mathrm{R}$ & $\mathrm{R}$ & $\mathrm{R}$ \\
\hline & & \multirow{9}{*}{ D.W. } & a & 180 & \multirow{3}{*}{1} & $\mathrm{R}$ & $\mathrm{R}$ & $\mathrm{R}$ & $\mathrm{R}$ & $\mathrm{R}$ & $\mathrm{R}$ \\
\hline & & & b & 360 & & $\mathrm{R}$ & $\mathrm{R}$ & $\mathrm{R}$ & $\mathrm{R}$ & $\mathrm{R}$ & $\mathrm{R}$ \\
\hline & & & c & 540 & & $\mathrm{R}$ & $\mathrm{R}$ & $\mathrm{R}$ & $\mathrm{R}$ & $\mathrm{R}$ & $\mathrm{R}$ \\
\hline & & & d & 180 & \multirow{3}{*}{2} & $17 \pm 1.5^{\star}$ & $\mathrm{R}$ & $\mathrm{R}$ & $\mathrm{R}$ & $\mathrm{R}$ & $\mathrm{R}$ \\
\hline & & & e & 360 & & $17 \pm 0.7^{\star}$ & $\mathrm{R}$ & $\mathrm{R}$ & $\mathrm{R}$ & $\mathrm{R}$ & $\mathrm{R}$ \\
\hline & & & f & 540 & & $17 \pm 0.7^{\star}$ & $\mathrm{R}$ & $\mathrm{R}$ & $\mathrm{R}$ & $\mathrm{R}$ & $\mathrm{R}$ \\
\hline & & & g & 180 & \multirow{3}{*}{3} & $17 \pm 0.0^{*}$ & $\mathrm{R}$ & $\mathrm{R}$ & $\mathrm{R}$ & $\mathrm{R}$ & $\mathrm{R}$ \\
\hline & & & h & 360 & & $17 \pm 2.0^{*}$ & $\mathrm{R}$ & $\mathrm{R}$ & $\mathrm{R}$ & $\mathrm{R}$ & $\mathrm{R}$ \\
\hline & & & i & 540 & & $17 \pm 1.5^{*}$ & $\mathrm{R}$ & $\mathrm{R}$ & $\mathrm{R}$ & $\mathrm{R}$ & $\mathrm{R}$ \\
\hline & & \multirow{9}{*}{ Ethanol } & $a$ & 180 & \multirow{4}{*}{1} & $\mathrm{R}$ & $\mathrm{R}$ & $\mathrm{R}$ & $\mathrm{R}$ & $\mathrm{R}$ & $\mathrm{R}$ \\
\hline & & & b & 360 & & $\mathrm{R}$ & $\mathrm{R}$ & $\mathrm{R}$ & $\mathrm{R}$ & $\mathrm{R}$ & $\mathrm{R}$ \\
\hline & & & c & 540 & & $\mathrm{R}$ & $\mathrm{R}$ & $\mathrm{R}$ & $\mathrm{R}$ & $\mathrm{R}$ & $\mathrm{R}$ \\
\hline & & & d & 180 & & $\mathrm{R}$ & $\mathrm{R}$ & $\mathrm{R}$ & $\mathrm{R}$ & $\mathrm{R}$ & $\mathrm{R}$ \\
\hline & & & e & 360 & \multirow[t]{2}{*}{2} & $\mathrm{R}$ & $\mathrm{R}$ & $\mathrm{R}$ & $\mathrm{R}$ & $\mathrm{R}$ & $\mathrm{R}$ \\
\hline & & & f & 540 & & $\mathrm{R}$ & $\mathrm{R}$ & $\mathrm{R}$ & $\mathrm{R}$ & $\mathrm{R}$ & $\mathrm{R}$ \\
\hline & & & g & 180 & \multirow{3}{*}{3} & $\mathrm{R}$ & $\mathrm{R}$ & $\mathrm{R}$ & $\mathrm{R}$ & $\mathrm{R}$ & $\mathrm{R}$ \\
\hline & & & h & 360 & & $\mathrm{R}$ & $\mathrm{R}$ & $\mathrm{R}$ & $\mathrm{R}$ & $\mathrm{R}$ & $\mathrm{R}$ \\
\hline & & & $\mathbf{i}$ & 540 & & $\mathrm{R}$ & $\mathrm{R}$ & $\mathrm{R}$ & $\mathrm{R}$ & $\mathrm{R}$ & $\mathrm{R}$ \\
\hline
\end{tabular}

$\mathrm{mm}=$ millimeter, ${ }^{\star}$ Mean \pm Standard Deviation, $\mathrm{n}=3, \mathrm{R}=$ Resistance, D.W.: Distilled water. P.E.: Plant Extract, S.S.: Sample Symbol, F: Nitrofurantoin; OFX: Ofloxacin; LEV: Levofloxacin; AK: Amikacin; CTX: Cefotaxim.

Table 8. Synergistic/antagonistic effect of $L$. inermis extracts and antibiotics against $S$. aureus.

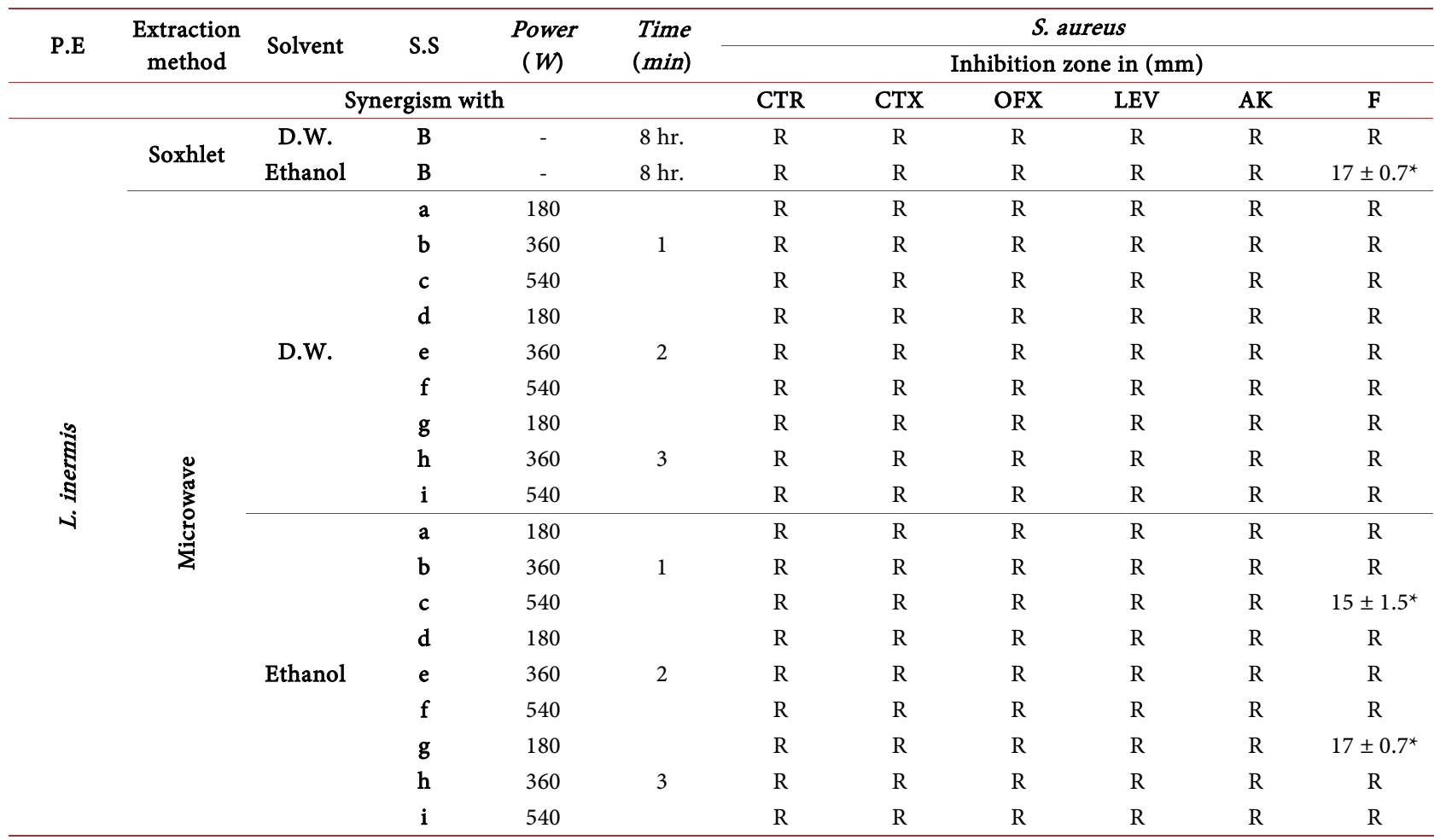

$\mathrm{mm}=$ millimeter, ${ }^{*}$ Mean \pm Standard Deviation, $\mathrm{n}=3, \mathrm{R}=$ Resistance, D.W.: Distilled water. P.E.: Plant Extract, S.S.: Sample Symbol, F: Nitrofurantoin; OFX: Ofloxacin; LEV: Levofloxacin; AK: Amikacin; CTX: Cefotaxim. 
Table 9. Synergistic/antagonistic effect of $L$. inermis extracts and antibiotics against $E$. coli.

\begin{tabular}{|c|c|c|c|c|c|c|c|c|c|c|c|}
\hline \multirow{3}{*}{ P.E } & \multirow{2}{*}{$\begin{array}{c}\text { Extraction } \\
\text { method }\end{array}$} & \multirow{2}{*}{ Solvent } & \multirow{2}{*}{ S.S } & \multirow{3}{*}{$\begin{array}{c}\text { Power } \\
(W)\end{array}$} & \multirow{3}{*}{$\begin{array}{l}\text { Time } \\
\text { (min) }\end{array}$} & \multicolumn{6}{|c|}{ E. coli } \\
\hline & & & & & & \multicolumn{6}{|c|}{ Inhibition zone in (mm) } \\
\hline & \multicolumn{3}{|c|}{ Synergism with } & & & CTR & CTX & OFX & LEV & $\mathrm{AK}$ & F \\
\hline \multirow{20}{*}{$\begin{array}{l}\text { : } \\
\text { ș } \\
\text { s }\end{array}$} & \multirow{2}{*}{ Soxhlet } & D.W. & B & - & $8 \mathrm{hr}$. & $\mathrm{R}$ & $\mathrm{R}$ & $\mathrm{R}$ & $\mathrm{R}$ & $\mathrm{R}$ & $\mathrm{R}$ \\
\hline & & Ethanol & B & - & $8 \mathrm{hr}$. & $\mathrm{R}$ & $11 \pm 1.0^{*}$ & $13 \pm 0.7^{\star}$ & $14 \pm 0.7^{\star}$ & $20 \pm 1.5^{\star}$ & $\mathrm{R}$ \\
\hline & \multirow{9}{*}{\multicolumn{2}{|c|}{ D.W. }} & a & 180 & \multirow{3}{*}{1} & $\mathrm{R}$ & $\mathrm{R}$ & $\mathrm{R}$ & $\mathrm{R}$ & $\mathrm{R}$ & $\mathrm{R}$ \\
\hline & & & b & 360 & & $\mathrm{R}$ & $\mathrm{R}$ & $\mathrm{R}$ & $\mathrm{R}$ & $\mathrm{R}$ & $\mathrm{R}$ \\
\hline & & & c & 540 & & $\mathrm{R}$ & $\mathrm{R}$ & $\mathrm{R}$ & $\mathrm{R}$ & $\mathrm{R}$ & $\mathrm{R}$ \\
\hline & & & d & 180 & \multirow{3}{*}{2} & $\mathrm{R}$ & $\mathrm{R}$ & $\mathrm{R}$ & $\mathrm{R}$ & $\mathrm{R}$ & $\mathrm{R}$ \\
\hline & & & e & 360 & & $\mathrm{R}$ & $\mathrm{R}$ & $\mathrm{R}$ & $\mathrm{R}$ & $\mathrm{R}$ & $\mathrm{R}$ \\
\hline & & & f & 540 & & $\mathrm{R}$ & $\mathrm{R}$ & $\mathrm{R}$ & $\mathrm{R}$ & $\mathrm{R}$ & $\mathrm{R}$ \\
\hline & & & g & 180 & \multirow{3}{*}{3} & $\mathrm{R}$ & $\mathrm{R}$ & $\mathrm{R}$ & $\mathrm{R}$ & $\mathrm{R}$ & $\mathrm{R}$ \\
\hline & & & h & 360 & & $\mathrm{R}$ & $\mathrm{R}$ & $\mathrm{R}$ & $\mathrm{R}$ & $\mathrm{R}$ & $\mathrm{R}$ \\
\hline & & & i & 540 & & $\mathrm{R}$ & $\mathrm{R}$ & $\mathrm{R}$ & $\mathrm{R}$ & $\mathrm{R}$ & $\mathrm{R}$ \\
\hline & 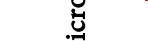 & \multirow{9}{*}{ Ethanol } & a & 180 & \multirow{4}{*}{1} & $\mathrm{R}$ & $\mathrm{R}$ & $\mathrm{R}$ & $\mathrm{R}$ & $\mathrm{R}$ & $\mathrm{R}$ \\
\hline & & & b & 360 & & $\mathrm{R}$ & $\mathrm{R}$ & $\mathrm{R}$ & $\mathrm{R}$ & $\mathrm{R}$ & $\mathrm{R}$ \\
\hline & & & c & 540 & & $\mathrm{R}$ & $9 \pm 0.7^{\star}$ & $11 \pm 2.0^{*}$ & $14 \pm 1.5^{\star}$ & $20 \pm 0.0^{*}$ & $\mathrm{R}$ \\
\hline & & & $\mathrm{d}$ & 180 & & $\mathrm{R}$ & $11 \pm 0.7^{*}$ & $13 \pm 1.5^{*}$ & $14 \pm 1.5^{*}$ & $20 \pm 1.0^{*}$ & $\mathrm{R}$ \\
\hline & & & e & 360 & \multirow[t]{3}{*}{2} & $\mathrm{R}$ & $11 \pm 1.0^{*}$ & $13 \pm 0.0^{*}$ & $16 \pm 1.5^{*}$ & $20 \pm 1.5^{*}$ & $\mathrm{R}$ \\
\hline & & & $\mathrm{f}$ & 540 & & $\mathrm{R}$ & $11 \pm 0.0^{*}$ & $13 \pm 0.7^{\star}$ & $16 \pm 0.7^{\star}$ & $20 \pm 0.7^{\star}$ & $\mathrm{R}$ \\
\hline & & & g & 180 & & $\mathrm{R}$ & $11 \pm 0.0^{*}$ & $13 \pm 0.7^{*}$ & $16 \pm 0.7^{*}$ & $20 \pm 0.7^{*}$ & $\mathrm{R}$ \\
\hline & & & h & 360 & \multirow[t]{2}{*}{3} & $\mathrm{R}$ & $11 \pm 1.5^{\star}$ & $13 \pm 1.0^{*}$ & $16 \pm 1.0^{*}$ & $20 \pm 0.7^{\star}$ & $\mathrm{R}$ \\
\hline & & & i & 540 & & $\mathrm{R}$ & $11 \pm 2.0^{*}$ & $13 \pm 1.0^{*}$ & $16 \pm 1.0^{*}$ & $20 \pm 1.5^{\star}$ & $\mathrm{R}$ \\
\hline
\end{tabular}

$\mathrm{mm}=$ millimeter, ${ }^{*}$ Mean \pm Standard Deviation, $\mathrm{n}=3, \mathrm{R}=$ Resistance, D.W.: Distilled water. P.E.: Plant Extract, S.S.: Sample Symbol, F: Nitrofurantoin; OFX: Ofloxacin; LEV: Levofloxacin; AK: Amikacin; CTX: Cefotaxim.

\subsection{Effect of Solvent System}

Through evaluation of antimicrobial activity of plant extracts and in synergisms/Antagonism, our results which obtained from ethanolic extracts (ethanol as a solvent) had shown better results than that obtained from aquatic extracts (water as a solvent). In addition most of aquatic extracts results had shown no inhibition zone. The same solvent system of samples used in extraction process in both methods MW and soxhlet in this study had shown mostly the same inhibition zone results, and some tests of MW samples had shown better than soxhlet samples. So, because of high capacity with high dielectric constant, ethanol is the best solvent in our experiments of extraction process. This evaluation is in agreement with previous studies [6] [13] [17] [18] [19] [20].

\subsection{Effect of Irradiation Time}

Through evaluation of antimicrobial activity of plant extracts and in synergisms/Antagonism, our results showed that, the inhibition zone is increased by increasing the time of extraction till reaching in a steady state values of inhibition zone. This may due to increasing of the time of extraction which lead to increasing of the yield of bioactive compounds till to reach a saturation although of increasing time. The samples of our plants in this study which extracted in one minute were in mostly had shown no inhibition zone except samples extracted by using a power $540 \mathrm{w}$ which had shown a weak inhibition zone. But in 
general the samples extracted in tow and three minutes had shown a maximum value and the same results of inhibition zone. So we can considered that the best with optimum time of extraction is a sample-d which extracted in tow minutes and had shown a maximum inhibition zone with a lowest power $180 \mathrm{w}$. Our results showed that, the MW method gave better results or at least same outputs as soxhlet method. We recommended MW method since it provides bioactive compounds in a very short time, mostly few minutes and a very low power. Other conventional methods may attribute to a degradation of bioactive compounds in long time of extraction process of conventional methods. This evaluation is in agreement with previous studies [6] [13] [17] [18] [19] [20].

\subsection{Effect of Microwave Power and Temperature}

Through evaluation of antimicrobial activity of plant extracts and synergisms/Antagonism effect, our results showed that, the inhibition zone is increased by increasing the MW power of extraction process till reaching in a steady state result of inhibition zone. This may due to increasing of the MW power of extraction which lead to increasing of the yield of bioactive compounds till reaching a saturation although of increasing MW power. The samples of our plants in this study which extracted in one minute were in mostly showed no inhibition zone, although of increasing of MW power except some samples extracted by using a power $540 \mathrm{w}$ which showed a weak of inhibition zone. But in most, they didn't show any effect by increasing MW power for samples extracted in two and three minutes which showed a maximum and the same results of inhibition zone. So we can consider that the best with optimum MW power of extraction is a sample-d which extracted at lowest power $180 \mathrm{w}$ in tow minutes and showed a maximum inhibition zone. According to the temperature, the results of ethanolic samples were better than aquatic samples. Due to high dielectric properties of ethanol, it leads to increasing of temperature of the medium solvent-solute, and thus increasing of the extraction of the bioactive compound, then had shown more of antimicrobial activity of inhibition zone. This evaluation is in agreement with previous studies [6] [13] [17] [18] [19].

\section{Conclusion}

In conclusion, the results from these studies were encouraging to find new antimicrobial agents or new ways that are effective for the treatment of infectious diseases caused by test pathogenic microorganism especially drug-resistant bacteria, after optimizing three parameters (solvent nature, irradiation time, microwave power) and evaluation of antimicrobial activity of plants extracts and in combination with antibiotics. In general, the positive inhibitory zone results of MW aquatic and ethanolic extracts samples were the best comparing with samples extracted by conventional method (soxhlet method in this study and some of the previous studies), especially more than $50 \%$ of aquatic and ethanolic sample results (extracted two minutes and MW power $180 \mathrm{w}$ ) had shown a maxi- 
mum magnitude of inhibition zone, though it consumed less time and power.

\section{Acknowledgements}

The authors thank Department of Biology and Biotechnology \& Department of Chemistry, Islamic University for providing excellent research facilities.

\section{Conflicts of Interest}

The authors declare no conflicts of interest regarding the publication of this paper.

\section{References}

[1] Saadoun, I., Al Challah, L.M., Aldhuhouri, F.M., Hamoudi, A.A. and Al Joubori, B. (2014) Antagonistic Effect of the Exotic Plant "Prosopis juliflora" Extract on Different Bacterial Pathogens. International Journal of Current Microbiology Applied Science, 3, 865-873.

[2] Eze, E.A., Oruche, N.E. and Eze, C.N. (2013) Interaction of the Extracts of Three Medicinal Plants with Antibiotics against Some Antibiotic Resistant Bacteria. Academic Journals, 8, 1360-1367.

[3] El-Hindi, M., Mosleh, F., Aldinee, S., Gharbiya, R. and El Kichaoui, A. (2017) Antibacterial Potentiality of Water Extract of Selected Honey Samples on Some Clinical Isolates. The Pharmaceutical and Chemical Journal, 4, 37-42.

[4] El Kichaoui, A., Abdelmoneim, A., Elbaba, H. and El Hindi, M. (2017) The Antimicrobial Effects of Boswellia carterii, Glycyrrhiza glabra and Rosmarinus officinalis Some Pathogenic Microorganisms. IUG Journal of Natural Studies, 25, 208-213.

[5] Yashwant, M., Hadkar, U.B., Nikita, D. and Bhagyashri, C. (2013) Microwave-Assisted Extraction of Phytoconstituents. Asian Journal of Phytomedicine and Clinical Research, 2, 73-86.

[6] Chemat, F. and Cravotto, G. (2012) Microwave-Assisted Extraction for Bioactive Compounds: Theory and Practice (Vol. 4). Springer Science \& Business Media, Berlin. https://doi.org/10.1007/978-1-4614-4830-3

[7] Mohamed, M.J., Tarek, E., Atef, M. and Zuhair, D. (2015) Synergistic Effect of Ficus sycomorus (Moraceae) Leaf and Stem-Bark Extracts against Some Selected Pathogens. International Journal of Scientific and Research Publications, 5, 492-496.

[8] Orwa, C., Mutua, A., Kindt, R., Jamnadass, R. and Anthony, S. (2009) Agroforestree Database: A Tree Reference and Selection Guide. Version 4, 1-5.

[9] Jain, V.C., Shaha, D.P., Sonani, N.G., Dhakara, S. and Patel, N.M. (2010) Pharmacognistical and Preliminary Phytochemical Investigation of Lawsonia inermis L. Leaf. Romanian Journal of Biology_Plant Biology, 55, 127-133.

[10] Lakshmi, T. and Geetha, R.V. (2011) Glycirrhiza glabra Linn Commonly Known as Licorice: A Therapeutic Review. International Journal of Pharmacy and Pharmaceutical Sciences, 3, 20-25.

[11] Asha, R., Navneet, K.V., Chaudhari, S.K., Vikash, C., Devendra, P.S. and Manoj, K.P. (2012) Phytochemical Constituent, Pharmacological Activities and Medical Uses through the Mellenia of Glycyrrhiza glabra Linn: A Review. International Research Journal of Pharmacy, 3, 45-55.

[12] Mohamed, M.J., Tarek, E. and Atef, M. (2016) The Antibacterial Effect of Some Medicinal Plant Extracts and Their Synergistic Effect with Antibiotics. Advances in 
Life Science and Technology, 46, 59-69.

[13] Mahaveer, D., Vivekananda, M. and Siva, H. (2009) Optimization of Microwave Assisted Extraction of Bioactive Flavonolignan-Silybinin. Journal of Chemical Metrology, 3, 13-23.

[14] Alzoreky, N.S. and Nakahara, K. (2003) Antibacterial Activity of Extracts from Some Edible Plants Commonly Consumed in Asia. International Journal of Food Microbiology, 80, 223-230. https://doi.org/10.1016/S0168-1605(02)00169-1

[15] El Kichaoi, A., El-Hindi, M., Mosleh, F., Shafie, A. and Elbashiti, T. (2016) In Vitro, Interaction of Some Antibiotics with Different Fruit Extracts on Some Pathogenic Bacterial Strains. International Journal of Development Research, 6, 7299-7304.

[16] Manoj, K., Agarwal, R.C., Sanjay, D., Ral, V.K. and Benito, J. (2009) Antimicrobial Activity of Aqueous Extract of Terminalia chebula Retz. on Gram Positive and Gram Negative. International Journal of Current Pharmaceutical Research, 1, 56-60.

[17] Noelia, F., Enma, C. and Herminia, D. (2014) Microwave Assisted Water Extraction of Plant Compounds. Journal of Chemical Technology \& Biotechnology, 2, 1-19.

[18] Faridah, K., Iqbal, A., Rosli, M.Y. and Zainal, A.M.Y. (2010) The Potential of Modified Microwave Extraction System (MMES) to Extract Bioactive Components from Ferns. International Journal of Engineering \& Technology IJET-IJENS, 10, 5-10.

[19] Jila, A., Bernd, O. and Mohsen, M. (2011) Extraction of Bioactive Chemical Compounds from the Medicinal Asian Plants by Microwave Irradiation. Journal of Medicinal Plants Research, 5, 495-506.

[20] Das, A.K., Mandal, V. and Mandal, S.C. (2013) Design of Experiment Approach for the Process Optimisation of Microwave Assisted Extraction of Lupeol from Ficus racemosa Leaves Using Response Surface Methodology. Phytochemical Analysis, 24, 230-247. https://doi.org/10.1002/pca.2403 